\title{
Sosyal Beceri Eğitimine Katılan Psikolojik Danışman Adaylarının Görüşleri*
}

\section{Views of Psychological Counselor Candidates Participating in Social Skills Training}

\author{
Murat Canpolat ${ }^{\mathrm{a}, * *}$, Meral Atıc1 ${ }^{\mathrm{b}}$ \\ a Öğr. Gör. Dr., İnönü Üniversitesi, Eğitim Fakültesi, Eğitim Bilimleri Bölümü, 44280, Malatya/Türkiye.Türkiye \\ ORCID: 0000-0003-2106-6474 \\ ${ }^{\text {b }}$ Prof. Dr. .,Çukurova Üniversitesi, Eğitim Fakültesi, Eğitim Bilimleri Bölümü, Adana /Türkiye. \\ ORCID: 0000-0003-0675-4439
}

\section{MAKALE BİLGISI}

\section{Makale Geçmişi:}

Başvuru tarihi: 04 Şubat 2019

Düzeltme tarihi: 09 Temmuz 2019

Kabul tarihi: 29 Temmuz 2019

Anahtar Kelimeler:

Sosyal beceri eğitimi

Psikolojik danıșman adayları

Aday görüşleri

\section{A R T I C LE INFO}

\section{Article history:}

Received 04 February 2019

Received in revised form 09 July 2019

Accepted 29 July 2019

\section{Keywords:}

Social skills training

Psychological counselor candidates

Candidates' views
ÖZ

Sosyal beceri eğitimine katılan psikolojik danışman adaylarının görüşlerinin incelendiği bu araştırmada nitel araştırma desenlerinden biri olan "durum çalışması" kullanılmıștır. Araştırma Mustafa Kemal Üniversitesi Eğitim Fakültesi Rehberlik ve Psikolojik Danışmanlık lisans eğitimine devam eden öğrencilerden seçilen katılımcılarla yapılmıştır. Araștırmada veri toplama aracı olarak araştırmacılar tarafından hazırlanan "Oturum Sonu Değerlendirme Formu" ve "Genel Değerlendirme Formu" kullanılmıştır. Elde edilen veriler içerik analizi ile çözümlenmiştir. Katılımcıların görüşleri elde edilen kazanım, yaşanan duygular, yaşanan farkındalıklar, yaşanan zorluklar, becerinin işlevselliği, eğitim program ve sürece ilişkin değerlendirmeler, becerinin geliștirilmesi için programa yönelik öneri seklinde kategorilere ayrılarak sunulmuștur. Araștırma sonuçları, sosyal beceri eğitiminin katılımcıların gelişimlerine katkı sağladığını göstermektedir.

\section{A B S T R A C T}

In this study which examined the views of psychological counselor candidates participating in social skills training, has been used one of the qualitative research methods is "case study". The research was conducted with the participants selected from the students attending Mustafa Kemal University Faculty of Education Guidance and Psychological Counseling. In the study, "The Final Evaluation Form" and the "General Evaluation Form" prepared by the researcher were used. The data were analyzed with content analysis. The opinions of the participants are presented in categories such as the acquisition, the feelings experienced, the awareness experienced, the functionality of the skill, the evaluation of the training program and the process, and the proposal for the program to improve the skills. The results of the research are the degree of interpretation of social skills training.

\section{Giriş}

Psikolojik danışmanların aldıkları eğitim, psikolojik danışma ve rehberlik hizmetlerinin etkililiği açısından önemlidir. Psikolojik danışmanların aynı ya da benzer eğitimi aldıkları halde mesleği icra ederken aynı düzeyde başarılı olmadıkları da görülebilmektedir. Alan yazında psikolojik danışmanlık ve rehberlik eğitimi alan psikolojik danışman adaylarının yalnız akademik başarılarının değil, diğer özelliklerinin de dikkate alınması gerektiğine ilişkin bir eğilim vardır (Korkut-Owen, Dost, Bugay \&Owen, 2014). Markert ve Monke (1990)'e göre psikolojik danışmanın yeterlilikleri ile ruh sağlığını yordayan ölçütler, akademik başarıyı yordayan ölçütler ile aynı değildir. Bu durum, üniversitede öğrenilen bilgilerin ve psikolojik danışmanlık becerilerinin başarılı olmada tek başına yeterli olmadığını, bunların dışında başka faktörlerinde gerekli olduğunu göstermektedir.

\footnotetext{
* Bu çalışma birinci yazarın 2017 yılında Prof. Dr. Meral Atıcı danışmanlığında Çukurova Üniversitesi, Sosyal Bilimler Enstitüsü Eğitim Bilimleri Anabilim Dalı'nda yürüttügü “'Sosyal Beceri Eğitiminin Psikolojik Danışman Adaylarının Sosyal Beceri ve Psikolojik İyi Olma Düzeylerine Etkisi” başlıklı doktora tezinden üretilmiştir.

** Sorumlu yazar/Corresponding author.

e-posta: murat.canpolat@inonu.edu.tr
} 
Psikolojik danışma ve rehberlik sürecinin etkili olmasında alan yazında birçok görüş bulunmaktadır. Hackney ve Cormier'e göre (2005), etkili bir psikolojik danışma sürecinin gerçekleşmesini sağlayan önemli faktörlerden biri bu süreçte aktif bir role sahip olan psikolojik danışmana ait faktörlerdir. Corey'e (1996) göre etkili bir psikolojik danışman "kim olduğunu, ne olabileceğini, amacını, değerlerini, güçlü ve zayıf yönlerini" bilir. "Yeni yaşantılara açık, otantik, dürüst, sabırlı, saydam, kendini açma konusunda uygun davranan, mizah anlayışına sahip, gerçekçi karar alabilen, danışanlarına olumlu model sunan", biridir. Dow ve Mayer (2004), "sosyal yeterlilikleri olan, sosyal beceri düzeyleri yüksek kișilerin problemleri etkili çözebildiklerini”" belirtmişlerdir. Sosyal beceri düzeyi yüksek bireyler, "diğer bireylerin duygu ve düşüncelerine uygun tepkide bulunma, diğer bireylerle olumlu sosyal etkileşim başlatma ve sürdürme, arkadaşlık kurma, sosyal ortamda karşılaştığı problemlerle etkili başa çıkma becerilerini" yerine getirirler (Rutherford, Mathur\&Quinn, 1998). Akkök (1996) ve Yüksel (1997) sosyal becerilerin etkili iletişimde bulunmayı kolaylaştırdığını ifade etmişlerdir. Akkoyun (2001) etkili psikolojik danışmanların sosyal beceri düzeyinin yüksek olması gerektiğini belirtmiştir. Nitelikli insan gücünün oluşması için sosyal ilişkileri güçlü olan ve sağlıklı ilişkiler kuran, sosyal beceri davranışları sergileyen psikolojik danışmanların gerekli olduğu belirtilmiştir (Paisley\& Hayes, 2003). Berns (2005) psikolojik danışmanların mempati, dinleme, geribildirim, duyguları tanıma ve ifade etme gibi terapötik becerilerinin ancak kişisel deneyimler sonucunda gelişebildiğini ifade etmiştir (Akt. Atıc1, Sanberk \&Ortakale, 2011). MusluKöseoğlu'na göre (1994) psikolojik danışmanların "kendine güvenen ve saygı duyan, duyarlı, sabırlı ve hoşgörülü olan, kendinden hoşnut olan, dişadönük, sorumluluk sahibi, kendi ve çevresiyle uyumlu, kendi ile barışık, deneyime açık, özgüveni yüksek, empatik, benlik saygısı yüksek, kararlı, sosyal ilişkileri güçlü gibi" özelliklere sahip olması gerekmektedir. Diğer taraftan Keyes, Shmotkin ve Ryff'a (2002) göre bireyin benliğini olumlu algılaması, sınırlılıklarını kabul edip kendisiyle bütünleşmesi, diğer bireylerle etkili iletişim kurabilmesi, çevresini kişisel ihtiyaç ve isteklerine cevap verecek biçimde şekillendirmesi, bağımsız ve girişimci olması, yaşamın anlam ve amacına ilişkin farkındalık sağlaması, yetenek ve becerilerinin farkında olması ve kendini geliştirmesi gibi özellikler psikolojik iyi olmayı yansıtmaktadır.

Özetle, psikolojik danışmanlık hizmetlerinin verimliliğinde psikolojik danışmana ait özellikler etkili görülmektedir. Psikolojik danışmanların sağlıklı sosyal ilişkiler geliştirmelerinin gerekli olduğu ve sağlıklı sosyal ilişkiler geliştirebilme becerilerinin deneyimler sonucu gelişebileceği düşünülmektedir. Bu nedenle bu araştırmada, sosyal becerilerin kazandırılmasına yönelik geliştirilen, davranışçı yöntemlere ve bireylerin performansına dayalı, bireysel veya grupla uygulanan bir eğitim ve müdahale yöntemi olan sosyal beceri eğitimi (Shepherd, 1983, Akt. Dikmeer, 1997), programı geliştirilmiş ve hazırlanan program psikolojik danışman adaylarına uygulanmıştır.

Buradan hareketle bu araştırmanın birkaç açıdan alana katkıda bulunacağı düşünülmektedir. Bunlardan birincisi; psikolojik danışmanlarda olması gerektiği düşünülen sosyal becerilerin psikolojik danışman adaylarına kazandırılmaya çalışılmasıdır. İkincisi; rehberlik ve psikolojik danışmanlık lisans programlarında doğrudan psikolojik danışman adaylarının sosyal becerilerini iyileştirmeye ve psikolojik iyi olma düzeylerini arttırmaya yönelik konu ve etkinliklere pek yer verilmemektedir. Bu çalışmayla bu eksiklik bir derecede olsa giderilmeye çalışılmıștır. Bu çalıșma, bu tür konu ve etkinliklere rehberlik ve psikolojik danışmanlık lisans programlarında yer verilmesi için bir zemin hazırlayabilecektir. Son olarak uygulanan sosyal beceri eğitimi, psikolojik danışman adaylarının mesleki bir uygulama içinde yer almaları ve ileride bir grup çalışmasını yönetebilmesi için gereken birtakım becerileri gözlemleme ve geliştirme olanağı sağlaması açısından da önemlidir.

Uygulanan eğitimle ilgili katılımcıların görüşlerini incelemek amacıyla nitel verilere ulaşmak için aşağıdaki sorulara yanıt aranmıştır.

- Araştırmanın deney grubunda yer alan psikolojik danışman adaylarının kendilerine uygulanan sosyal beceri eğitim programına ilişkin görüşleri (etkinlik ve yöntemlerin etkililiği gibi) nelerdir?

- Araştırmanın deney grubunda yer alan psikolojik danışman adaylarının programın uygulanma sürecindeki deneyimleri ve yaşantılarına ilişkin görüşleri nelerdir?

\section{Yöntem}

\subsection{Araștırma Deseni}

Sosyal beceri eğitimine katılan psikolojik danışman adaylarının görüşlerinin incelendiği bu araştırmada nitel araştırma desenlerinden biri olan "durum çalışması" kullanılmıştır. Durum çalışması, güncel bir olguyu kendi gerçek yaşam çerçevesi içinde çalışan, olgu ve içinde bulunduğu içerik arasındaki sınırların kesin hatlarıyla belirgin olmadığı ve birden fazla kanıt veya veri kaynağının mevcut olduğu durumlarda kullanılan, görgül bir araştırma yöntemidir (Yıldırım \& Şimşek, 1999). Durum çalışması ile sosyal beceri eğitiminin amaca hizmet edip etmediği anlaşılmaya çalışılmıştır. Nicel sonuçlara bağlı kalmaksızın yani eğitim sonucunda anlamlı farklılık çıkıp çıkmadığına bakılmaksızın katılımcıların görüşlerine başvurulmuştur. Böylece programa katılan psikolojik danışman adaylarının süreç hakkında gözlem ve deneyimlerine ilişkin veriler elde edilmiştir.

\section{2. Çalışma Grubu}

Araştırmada yer alan katılımcılar 2015-2016 eğitim-öğretim yılında Mustafa Kemal Üniversitesi Eğitim Fakültesi Rehberlik ve Psikolojik Danışmanlık lisans eğitimine devam eden 134 öğrenci arasından seçilmiştir. Lisans eğitimine devam eden öğrencilerden ölçekleri cevaplamaya gönüllü olan 125 öğrenciye Psikolojik İyi Olma Ölçekleri ve Sosyal Beceri Envanteri uygulanmıştır. 125 öğrenciden toplanan veriler SPSS programına aktarılırken 12 öğrenciye ait ölçeklerde eksik veri olduğundan çıkarılmıştır. Dört (4) tane değer de uç değer olduğundan dolayı çıkarılmıştır. 109 öğrenciden elde edilen veri ile analizlere devam edilmiştir.

İlk önce iki değişken olan sosyal beceri ve psikolojik iyi olma puanları arasında 109 veri üzerinden korelasyona bakılmış $\mathrm{r}=.59$ olarak bulunmuştur. İki değişken arasında orta düzeyde bir ilişki olduğu görülmüştür. Çalışmada 
sosyal beceri eğitimi verileceğinden gruplar sosyal beceri puanları dikkate alınarak oluşturulmuştur. Sosyal beceri puanlarının normal dağılım sergileyip sergilemediklerini tespit etmek için çarpıklık-basıklık (skewness-kurtosis) değerleri ve Kolmogorov-Smirnov (K-S) testi değerlerine bakılmıştır. Çarpıklık katsayısı -.009, basıklık katsayısı .090 bulunmuştur. $\mathrm{Bu}$ değerlerin \pm 1 aralığında yer alması normallikten aşırı sapmalar olmaması şeklinde yorumlanmaktadır (Büyüköztürk, 2002). KolmogorovSmirnov (K-S) testi sonucu $\mathrm{p}=.200$ olarak (p>.05) bulunmuştur. Bu testte anlamlılık seviyesinin .05 'ten büyük olması, verilerin normal dağılımında sapmalar olmadığını göstermektedir (George \&Mallery, 2012). Ölçekten alınan sonuçlara göre sosyal beceri düzeyi ortalamanın $(X=282.72, \mathrm{Ss}=28.35) 1$ ve 2 standart sapma altında olan öğrencilerle görüşme yapılarak yapılan çalışma hakkında genel bilgiler (eğitimin amac1, süresi, grubun kaç kişiden oluşacağı, kurallar gibi) verildikten sonra, araştırmaya gönüllü olarak katılmak isteyen 28 öğrenci belirlenmiştir. $\mathrm{Bu}$ gönüllü öğrenciler kura yöntemi ile seçkisiz olarak iki gruba, her grupta 14 öğrenci olacak şekilde atanmıştır. Sonra bu iki grup yine kura yöntemi ile seçkisiz olarak deney grubu ve kontrol grubu olarak atanmıştır.

\subsection{Veri toplama Araçları}

\subsubsection{Oturum Sопи Değerlendirme Formu}

Oturum sonu değerlendirme formu araştırmacılar tarafından geliştirilmiştir. Formda 3 soru yer almaktadır. Bu form; oturumda ele alınan konu ile ilgili kendilerinde neleri fark ettikleri, oturumda kazandıkları becerileri günlük yaşamda ne derece ve nasıl kullanabilecekleri ve oturumda ele alınan beceriyi geliştirmeleri için daha farklı neler yapılabileceğine ilişkin sorulardan oluşmaktadır.

$\mathrm{Bu}$ sorularla katılımcıların oturumda işlenen konu ile kendilerinde neleri fark ettikleri, kazandığı bilgi ve beceriyi ne düzeyde kullanabilecekleri, bu beceriyi geliştirmesi için başka neler yapılabileceği, oturum sürecinin işleyişi, etkinlikler ve yöntemlerin etkililiğine dair düşüncelerine ulaşmak hedeflenmiştir.

\subsubsection{Genel Değerlendirme Formu}

Genel değerlendirme formu araştırmacılar tarafından geliştirilmiştir. Formda 9 soru yer almaktadır. $\mathrm{Bu}$ form; eğitim sürecini genel olarak nasıl değerlendirdikleri, eğitim sürecinde neleri fark ettikleri, hangi oturumdan daha çok yararlandıkları, hangi oturumdan daha az faydalandıkları, eğitim programında en zorlayıcı şeylerin neler olduğu, programda en çok dikkat çeken şeylerin neler olduğu, programa dair önerileri ve kendilerinde gözlemledikleri değişimlere ilişkin sorulardan oluşmaktadır.

$\mathrm{Bu}$ sorularla katılımcıların oturumlarda işlenen konularla ilgili kendilerinde neleri fark ettiklerine, en çok neyi severek yaptıklarına, en çok neleri yapmakta zorlandıklarına, kendilerinin güçlü ve zayıf yönleri hakkında ne düşündüklerine, programa dair düşüncelerine ve bu eğitimlere ilişkin önerilerine ulaşmak hedeflenmiştir.

Formların hazırlanması aşamasında sorular hazırlandıktan sonra bir uzmanın görüşü alınmıştır. Bazı soruların benzer amaca hizmet ettiği, bazı soruların gereksiz olduğu, bazı soruların da değiştirilmesi yönünde geribildirimler alınmıştır. Değişiklikler yapıldıktan sonra oturum sonu değerlendirme formu her oturumun sonunda ev ödevi olarak verilmiştir. Genel değerlendirme formu son oturumun uygulanmasından bir gün sonra katılımcılar çağrılarak formları doldurmaları istenmiştir. Katılımcıların soruları anlamakta zorlanmadıkları görülmüştür.

\subsection{Verilerin Toplanmas1}

Araştırmanın verileri sadece deney grubundan elde edilmiştir. Araştırmacılar tarafından hazırlanan Oturum Sonu Değerlendirme Formu ve Genel Değerlendirme Formu ile nitel veriler elde edilmiştir. Oturum Sonu Değerlendirme Formu her oturumun sonunda ödev olarak verilmiş bir sonraki oturumun başında toplanarak dosyada saklanmıştır. Nadiren bazı öğrencilerin formları getirmedikleri görülmüştür. Genel Değerlendirme Formu ise son oturumdan bir gün sonra deney grubundaki katılımcılar çağrılarak uygulanmıştır.

\subsection{Programın Genel Kapsamı}

Psikolojik danışman adaylarının sosyal beceri ve psikolojik iyi olma düzeylerini arttırmaya yönelik geliştirilen sosyal beceri eğitim programı bilişsel yaklaşım, davranışçı yaklaşım, insancıl yaklaşım ve sosyal bilişsel öğrenme modeli göz önünde bulundurularak hazırlanmış ve deney grubuna 11 hafta boyunca haftada bir kez yaklaşı 90 dakika süreyle uygulanmıştır.

$\mathrm{Bu}$ araştırmada uygulanan grup çalışması grup rehberliği temellidir. Grup rehberliği, bireylerin kendilerini geliştirmelerine, kendilerini ve imkânlarını tanımalarına, gerçekçi ve uygun planlar yapmalarına, gerçekçi ve uygun seçimler yapmalarına, kendilerini doğru yönlendirmelerine imkân sağlayan grup etkinlikleri ve süreçleri olarak tanımlanabilir (Özgüven, 1999). Grup rehberliğinin odağında konu vardır ve yaklaşımı daha çok bilişseldir. Bazı yazarlar (Kepçeoğlu, 2000; Myrick, 2003; Tan, 1992; Ülkü, 1977; Voltan Acar, 2001), grup rehberliğinin daha çok öğretime yakın olduğunu ve bilgi vermeyi hedeflediğini söylemektedirler. Grup rehberliğinde üyeler, kendilerini daha çok fark ederek olumsuz yönlerini düzeltmeye, olumlu yönlerini ise geliştirmeye yönelebilirler (Tan, 1992).

Sosyal beceri eğitimi grup uygulamaları esnasında sorucevap, tartışma, geribildirim, rol oynama, model olma, kendini açma, ben dili, düz anlatım, örnek olay, ev ödevi, oyun gibi yöntem ve tekniklerden faydalanılmıştır.

\subsection{Programın Hazırlanmas1 ve Uygulanmas}

Programın hazırlanma sürecinde sosyal beceri ve psikolojik iyi olma kavramları ile ilgili literatür taraması sonucu programlarda ele alınması gereken başlıklar belirlenmiştir. $\mathrm{Bu}$ doğrultuda bir inceleme yapıldıktan sonra program hazırlanmış ve hazırlanan program için uzman görüşü alınmıştır. Bu geribildirimler oturumda ele alınan konu başlıkları, işlenişi, yöntem ve tekniklerin uygunluğu, etkinliklerin amaca uygunluğu,etkinliklerin sırası ve zamanın planlanması konuları üzerinde olmuştur. $\mathrm{Bu}$ geribildirimler doğrultusunda programa son şekli verilmiştir.

Uzman görüşü alındıktan sonra gerekli düzeltmeler yapılarak ön deneme uygulamasına geçilmiştir.Deneme 
uygulaması araştırmacılardan biri tarafindan haftada bir olmak üzere ortalama 11 hafta boyunca 90 dakika süren oturumlar şeklinde yapılmıştır. Oturumlar video ile kayıt altına alınmıştır. Araştırmacılar her bir oturumu izlemiş, gördüğü aksaklıklar ve yanlışlıkların bir sonraki oturumda düzeltilmesi için o oturuma dair notlar almıştır. Bu notlar grup liderinin danışmanlık becerileri, oturumda ele alınan konunun işlenişi, yöntem ve tekniklerin uygunluğu, etkinliklerin amaca uygunluğu, öğrencilerin katılım durumları, etkinliklerin sırası ve zamanın planlanması konuları üzerinde olmuştur. $\mathrm{Bu}$ geribildirimler doğrultusunda programa son şekli verilmiştir. Asıl uygulama araştırmacılardan biri tarafından haftada bir olmak üzere ortalama 11 hafta boyunca 90 dakika süren oturumlar şeklinde yapılmıştır.

\section{Sosyal Beceri Eğitim Programı}

1. oturum: Tanışma, iletişimi başlatma ve sürdürme, sosyal becerinin niteliğini kavrama

2. oturum: Sözel olmayan ipuçlarl, duygular ve beden dili

3. oturum: Sorumluluklarım

4. Oturum: Anlat bakalim

5. oturum: Kendini kabul ve bakış açısı

6. oturum: Atılganim

7. oturum: Karar verme

8. oturum: Problem Çözme

9. oturum: Empati

10. oturum: Işbirliği

\section{1. oturum: Vedalaşma}

Oturumlarda katılımcıların; birbiriyle tanışma, göz teması kurma, başkaları ile tanışma, tanıdıklarını başkaları ile tanıştırma, iletişimi sürdürme, kendisinin sözel olmayan ipuçlarını anlama, karşıdakinin sözel olmayan ipuçlarını anlama, yaşanan duyguları tanıma, iletişimde sözel olmayan ipuçlarının önemini anlama, sorumluluk sahibi olmanın önemini anlama, kendilerine ve başkalarına karşı olan sorumluluklarının farkına varma, başkalarına karşı sorumlu davranışlarda bulunmanın faydalarını kavrama, konuşma becerilerinde gelişme, topluluk önünde konuşma, kendilerine karşı olan tutumlarını gözden geçirme, başkalarına karşı olan tutumlarını gözden geçirme, kendilerini olduğu gibi kabul etme, hayata olumlu pencereden bakma, atılgan, saldırgan, pasif-saldırgan ve çekingen davranışları ayırt etme, atılgan davranışlar sergileme, karar verme adımlarını öğrenme, karar verme becerilerini geliştirme, kendi karar verme tarzlarını fark etme, problem çözme adımlarını öğrenme, problem çözme becerilerini geliştirme, empati kavramını içselleştirmelerinde yardımcı olma, iletişimde empati becerisini etkili biçimde kullanma, empati becerisini geliştirme, grupla iş birliği yapma becerilerini geliştirme, iş birliği yapmanın önemini anlama, kendilerinin içinde bulundukları grubun bir parçası olduğunu anlamalarını sağlama konularında gelişmeleri hedeflenmiştir.

Sosyal beceri eğitimi grup uygulamaları esnasında sorucevap, tartışma, geribildirim, rol oynama, model olma, kendini açma, ben dili, düz anlatım, örnek olay, ev ödevi, oyun gibi yöntem ve tekniklerden faydalanılmıştır.

\subsection{Verilerin Analizi}

Her oturumun sonunda katilımcilar tarafindan doldurulan Oturum Sonu Değerlendirme Formu ve programın bitiminden sonra doldurulan Genel Değerlendirme Formları ile elde edilen nitel veriler içerik analizi ile incelenmiştir. İçerik analizinde ilk önce içerik analizinin ilk ve önemli aşamaları olan açık ve seçici kodlama süreci izlenmiştir (Strauss \&Corbin, 1990, Akt. At1c1, 2006). Oturum sonu formundan ve genel değerlendirme formundan elde edilen veriler word programına aktarılmış (23 sayfa) ardından birkaç kez okunmuş ve kodlama yapılmıştır. Aynı şekilde elde edilen veriler bir uzman tarafindan da okunmuş ve kodlama yapılmıştır. Elde edilen kodlar karşılaştırılmış ve sonuç olarak, verileri kodlama sürecinde araştırmacılar tarafından yapılan kodlamaların büyük oranda benzer olduğu görülmüş ve çok küçük bazı değişiklikler yapılmıştır. Kodlama yaparken ilgili literatür ve araştırma soruları göz önünde bulundurulmuştur. Daha sonra kodları altında toplayacak kategoriler belirlenmiştir. İçerik analizi sonucunda ortaya çıkan kategori ve kavramlar tablolar halinde sunulmuştur.

\subsection{Verilerin Güvenirlik ve Geçerlik Çalışmaları}

$\mathrm{Bu}$ araştırmada diş güvenirlik için veri toplama ve analiz yöntemiyle ilgili ayrıntılı açıklamalar yapılmış, araştırmanın ham verileri başkaları tarafindan incelenebilecek şekilde saklanmıştır. İç güvenirliğin sağlanması için sonuçların elde edilen verilere dayalı olduğunun kanıtlanması açısından analiz sürecinde bir uzmandan yardım alınmış ve kodlama karşılaştırması yapılmıştır. (Yıldırım \& Şimşek, 1999).

Kodlayıcılar arasındaki görüş birliğini belirlemek için yapılan güvenirlik çalışmasında Miles ve Huberman'ın (1994), ortaya koyduğu güvenirlik formülünden faydalanılmıştır (Güvenirlik $=$ (Görüş Birliği/(Görüş Birliği+Görüşs Ayrılığı). Güvenirlik \% 93.93 olarak bulunmuştur. Nitel araştırmalarda görüş birliğinin farklı ölçütleri bulunmaktadır. Turner ve Carslon'a (2003) göre uzmanlar arası görüş birliğinin 0.75 ve daha yüksek olması yeterlidir.

Oturum sonu ve genel değerlendirme formlarının kapsam geçerliği için öncelikle araştırmacılar tarafından hazırlanan sorular, soruların araştırmanın amacı doğrultusunda bilgiler ortaya koyup koymadığı, soruların sırasının uygunluğu, ifadelerin anlaşılır olup olmadığı konusunda iki öğretim üyesine sunulmuş ve önerileri doğrultusunda düzenlemeler yapilmıştır.

$\mathrm{Bu}$ araştırmada iç geçerlik için değerlendirme formu yoluyla ayrıntılı ve derinlemesine bilgi toplanmış, toplanan veriler ayrıntılı rapor edilmiş, bulguların kendi içinde anlamlı ve tutarlı olup olmadığı gözden geçirilmiştir. Bulguları sunarken katılımcıların görüşlerinden doğrudan alıntılara yer verilmiş, kodlama sürecinde araştırmacılar tarafindan yapılan kodlamaların ve bulunan temalar veriye uygunluğu açısından uzman kişi tarafından incelenmiştir. (Yıldırım \& Şimşek, 1999). 


\section{Bulgular}

Katılımcıların sosyal beceri eğitim programı uygulamalarıyla ilgili görüşlerini yazarak belirttikleri "Oturum Sonu Değerlendirme Formu" ve "Genel
Değerlendirme Formun"ndan elde edilen verilerin analizi sonucunda elde edilen kazanım, yaşanan duygular, yaşanan farkındalıklar, yaşanan zorluklar, becerinin işlevselliği, eğitim programı ve sürece ilişkin değerlendirmeler, becerinin geliştirilmesi için programa yönelik öneri şeklinde temalar belirlenmiştir.

Psikolojik danışman adaylarının oturumlardan elde ettikleri kazanımlara ilişkin görüşleri Tablo 1'de sunulmuştur.

Tablo 1. Psikolojik Danışman Adaylarının Oturumlardan Elde Ettikleri Kazanımlara İlişkin Görüşleri

$\begin{array}{lc}\text { Yeterli Kazanım } & \\ \text { İlişkiyi başlatma ve sürdürebilme } & 14 \\ \text { Grupla bir işi yürütebilme } & 8 \\ \text { Duygulara yönelik beceri } & 6 \\ \text { Saldırgan davranışlarla başa çıkabilme } & 4 \\ \text { Plan yapabilme ve problem çözme } & 4 \\ \text { Toplam } & \mathbf{3 6} \\ \text { Yetersiz Kazanım } & \\ \text { Programdan kaynaklı } & 2 \\ \quad \text { İlişkiyi başlatma ve sürdürebilme } & \\ \text { Grup üyelerinin kendilerinden kaynaklı } & \\ \quad \text { İlişkiyi başlatma ve sürdürebilme } & 6 \\ \quad \text { Plan yapabilme ve problem çözme } & 2 \\ \text { Toplam } & \mathbf{1 0} \\ \text { Genel toplam } & \mathbf{4 6}\end{array}$

Elde edilen kazanım teması "yeterli kazanım" ve "yetersiz kazanım" olmak üzere iki alt temadan oluşmaktadır. Psikolojik danışman adaylarının oturumlardan elde ettikleri yeterli kazanımlar; ilişkiyi başlatma ve sürdürebilme becerileri, grupla bir işi yürütme becerileri, duygulara yönelik beceriler, saldırgan davranışlarla başa çıkabilme becerileri, plan yapabilme ve problem çözme becerileri başlıkları altında toplanmıştır. Bu konuda katılımcıların görüşlerine örnek olabilecek alıntılar aşağıda yer almaktadir.

Birileriyle aynı durumda kalırsam daha rahat davranabilirim. Ne konuşacağımı kestirebilirim (K7).

Atılganlık konusunda aşırı bir sıkıntım olduğunu düşünmüyordum fakat burada tekrar bu konuyu ele alınca hala bir takım sıkıntılarım olduğunu fark ettim. Bunları düzeltmek için bu oturum çok verimli oldu. Fikir alışverişi epey faydalıydl (K5).

...Yani demek istediğim zamanı başa harcamak değildi bu etkinlik, faydalıydl. Mesela sorumluluk bilincim
8

4

36

2

6

10

46

arttı. Her oturum sonrasi o formları doldurmak, zamanında buluşacağımız ortamda olabilmek, yetişmek için bazı işlerini ertelemek $v b$. bunları yaşadım (K3).

Psikolojik danışman adayları oturumlardan elde edemedikleri kazanımları programdan ve kendilerinden kaynaklı sebeplere bağlamaktadırlar. Kendilerine bağlı nedenlerin daha çok olduğu dikkat çekmektedir. Elde edilemeyen kazanımlar ilişkiyi başlatma ve sürdürme becerileri, plan yapma ve problem çözme başlıkları altında toplanmıştır. $\mathrm{Bu}$ konuda katılımcıların görüşlerine örnek olabilecek alıntılar aşağıda yer almaktadır.

Beden dili konusunda pek yetkin olmadı̆̆ımı ve bu konuda bir şeyler yapmam gerektiğini diyebiliriz (K5).

Illetişim becerisi günlük yaşamda kullanabileceğim bir beceri. Henüz kazanmadığımı düşünüyorum (K9).

Psikolojik danışman adaylarının oturumlarda elde ettikleri farkındalıklara ilişkin görüşleri ise Tablo 2'de sunulmuştur

Tablo 1. Psikolojik Danışman Adaylarının Oturumlarda Elde Ettikleri Farkındalıklara İlişskin Görüşleri

\begin{tabular}{lc}
\hline Olumlu Özellikler & f \\
İlişkiyi başlatma ve sürdürebilme & 29 \\
Grupla bir işi yürütebilme & 27 \\
Kendini tanıma & 14 \\
Kendini geliştirme ihtiyacı hissetme & 13 \\
Duygulara yönelik beceri & 8 \\
Plan yapabilme ve problem çözme & 6 \\
Toplam & $\mathbf{9 7}$
\end{tabular}

Toplam

\section{Olumsuz Özellikler}

İlişkiyi başlatamama ve sürdürememe 37

$\begin{array}{ll}\text { Stres yaratan durumlar ile başa çıkamama } & 10\end{array}$

Plan yapamama ve problem çözememe 8

Kendini tanımama

Grupla bir işi yürütememe 4

Saldırgan davranıșlarla başa çıkamama 4

Duygulara yönelik beceri eksikliği 2

Toplam 


\section{Genel toplam}

Elde edilen farkındalık teması "olumlu özellikler" ve "olumsuz özellikler" olmak üzere iki alt temadan oluşmaktadır. Psikolojik danışman adaylarının oturumlardan elde ettikleri olumlu farkındalıklara ilişkin görüşleri; ilişkiyi başlatma ve sürdürebilme, grupla bir işi yürütebilme, kendini tanıma, kendini geliştirme ihtiyacı hissetme, duygulara yönelik beceri, plan yapabilme ve problem çözme başlıkları altında toplanmıştır. Bu konuda katılımcıların görüşlerine örnek olabilecek alıntılar aşağıda yer almaktadir.

Bu konuda insanın kendini geliştirebileceğini düşünüyorum. Daha iyi gözlem analiz yapar ve empati kurarsak bu konuda kendimizi geliştirebiliriz. En önemlisi önyargılarımızdan kurtularak bu işe başlayabiliriz. Çünkü önyargllar sağllklı tespit, gözlem ve analiz yapmamızı engeller (K10).

Daha eğitimi yaşantıma tam olarak uygulamasam da en azından davranışlarımın nedenlerini algllayabiliyorum ve diğer insanların duygu durumunu kavrayabiliyorum. Daha sonralarl oturum bilgilerimi de yerine göre kullanabileceğime inanıyorum (K2).

Empati kurmada insanlarl anlamada iyi olduğumu fakat iletişimi başlatma konusunda iyi olmadı̆̆ımı fark ettim (K10).

Acele kararlar vermenin problemimi çözmek yerine daha da büyütebileceğini fark ettim (K8).

Farklı ve değişik bir şey görmedim ama dikkatimi çeken nokta ilk haftalar hiç konuşmayan kişilerin daha

\section{9}

sonra aktif şekilde konuşmaları. Demek ki oturumlar faydall olmuş (K11).

Psikolojik danışman adaylarının oturumlardan elde ettikleri olumsuz farkındalıklara ilişkin görüşleri; ilişkiyi başlatamama ve sürdürememe, stres yaratan durumlar ile başa çıkamama, plan yapamama ve problem çözememe, kendini tanımama, grupla bir işi yürütememe, saldırgan davranışlarla başa çıkamama, duygulara yönelik beceri eksikliği başlıkları altında toplanmıştır. $\mathrm{Bu}$ konuda katılımcıların görüşlerine örnek olabilecek alıntılar aşağıda yer almaktadır.

Toplum önünde konuşurken çok heyecanlandığımı ve düşüncelerimi rahat bir şekilde ifade edemediğimi gördüm. Illetişim kurmada çok önemli olan göz temasını da kurmadığımı fark ettim (K10).

Beden dilimi pek fazla kullanmadı̆̆ımı ve etrafimdaki insanların da beden dilinin ne anlattı̆̆ını pek anlayamadı̆̆ımı fark ettim (K4).

Insanlarla göz teması kurmadı̆̆ımı. Hazırlıksız sunum yapmanın insana heyecan kattığını. Sunum yaparken kendim olmadı̆̆ımı (K2).

Beden dilimi pek fazla kullanmadığımı ve etrafimdaki insanların da beden dilinin ne anlattı̆̆ını pek anlayamadı̆̆ımı fark ettim. Duygu değişiminde çok dengesiz olduğumu 2 saniye arayla duygularımın çabuk de ğiştiğini fark ettim (K4).

Psikolojik danışman adaylarının oturumlarda yaşadıkları duygulara ilişkin görüşleri de Tablo 3'te sunulmuştur.

Tablo 2. Psikolojik Danışman Adaylarının Oturumlarda Yaşadıkları Duygulara İlişkin Görüşleri

\author{
İyi Hissettiren Duygular \\ Rahat olma \\ Zevk alma \\ Heyecanlanmama \\ Çekingenlikte azalma \\ Toplam 12 \\ İyi Hissettirmeyen Duygular \\ Önce Heyecanlanma \\ Gergin olma \\ Çekingen olma \\ Toplam \\ Genel toplam \\ Oturumlarda yaşanılan duygular teması "iyi hissettiren \\ duygular" ve "iyi hissettirmeyen duygular" olmak üzere iki \\ alt temadan oluşmaktadır. İyi hissettiren duygular; rahat \\ olma, zevk alma, heyecanlanmama ve çekingenlikte azalma \\ başlıkları altında toplanmıştır. Bu konuda katılımcıların \\ görüşlerine örnek olabilecek alıntılar aşağıda yer \\ almaktadır.
}

Özellikle şunu belirtmeliyim $k i, \quad b u$ oturumda diğerlerinden daha aktif ve rahattım. Yani artık ortama alıştım. Ve bunu hareketlerime yansitabiliyorum. Kendimi daha rahat ifade edip utanıp çekinmeden her türlü faaliyette bulunabiliyorum (K3).

Günlük hayatta biraz daha kolay gelen durumlar topluluk önünde zorlanarak ifade edebildiğimi fark ettim

\section{f}

9

1

1

1

7

3

2

diyebilirim. Bunun dışında kendimi farkl bir isimle tanıtmaktan büyük bir zevk aldığımı söyleyebilirim (K5).

$\mathrm{Bu}$ oturumda ilk oturumdaki gerginliğim ve çekingenliğimin azaldı̆̆ını ve daha fazla verim almaya başladı̆̆ımı fark ettim (K6).

Psikolojik danışman adaylarının ifade ettikleri iyi hissettirmeyen duygular; önce heyecanlanma, gergin olma ve çekingen olma başlıkları altında toplanmıştır. Bu konuda katılımcıların görüşlerine örnek olabilecek alıntılar aşağıda yer almaktadır.

Topluluk karşısında konuşma konusunda daha çok eksik olduğumu fark ettim. Sahneye çıkmadan önce heyecan yaşadığımı ve sahneye çıkınca heyecanımın azaldığını gördüm (K6). 
Senaryo uygulama beni çok zorladı ancak ĕ̌̆iticiliği de yüksekti ama çekimser kaldığımı hissettim senaryo uygularken (K2).
Psikolojik danışman adaylarının oturumlardan ele alınan becerilerin işlevselliğine ilişkin görüşleri Tablo 4'te sunulmuştur.

Tablo 3. Psikolojik Danışman Adaylarının Oturumlarda Ele Alınan Becerilerin İşlevselliğine İlişkin Görüşleri

\section{Kullanıldı̆̆ı Alanlar}

İlişkiyi başlatma ve sürdürebilme 34

Duygulara yönelik beceri 12

Grupla bir işi yürütebilme $\quad 10$

Plan yapabilme ve problem çözebilme $\quad 8$

Saldırgan davranışlarla başa çıkabilme $\quad 1$

Toplam

\section{Kullanma Niteliği}

Daha doğru olarak

Daha rahat olarak

Daha dikkatli olarak

Duygusal açıdan kontrollü olarak

Soğukkanlı olarak

Toplam

\section{Becerinin Katkısı}

Mutlu olma

Özgüvenli olma

Güvenilir olma

Rahat olma

9

11

4

Özerk olma

Hoşgörülü olma

Girișimci olma

Aktif olma

Toplam

Genel toplam

Ele alınan becerilerin işlevselliği teması "kullanıldığı alanlar", "kullanma niteliği”" ve "becerinin katkısı" olmak üzere üç alt temadan oluşmaktadır. Psikolojik danışman adaylarının becerinin kullanıldığı alanlara ilişkin görüşleri; ilişkiyi başlatma ve sürdürebilme, duygulara yönelik beceri, grupla bir işi yürütebilme, plan yapabilme ve problem çözebilme, saldırgan davranışlar ile başa çıkabilme şeklinde ele alınmıştır. Bu konuda katılımcıların görüşlerine örnek olabilecek alıntılar aşağıda yer almaktadır.

Günlük hayatta insanlarla daha iyi iletişim kurmamı sağlar (K14).

Daha çok işe yaramaya çalışabilirim. Aldı̆̆ım sorumluluklarl yerine getirmekte daha hassas olabilirim (K1).

Kendimizi tanıyı bunu ifade edebilmek tabi $k i$ iletişimimizin güçlü olmasını sağlar. Kendimizi insanlara anlatabilmemiz belki de o insanın bizim hakkımızdaki bir takım olumsuz düşüncelerini değiştirir. Biz de kendimizde var olan bizim farkında olmadı̆̆ımı yeteneklerimizi keşfedebiliriz. Farklı ilgi alanları edinebiliriz (K3).

Topluluk önünde konuşma insanın her yerde karşısına çıkacak bir durumdur. Bunu yapmamız gerektiğinde biraz daha soğukkanlı davranabilmek etkili konuşmalar yapabilmek için kullanabilirsiniz (K5).

Okulda hocaların istediği slaytlart sunarken daha sakin olarak ve daha iyi hazırlanarak. Kendim olarak aslında daha iyi anlatıcı olduğumu düşünerek (K2).

Insanların sıkıntılarını daha iyi anlayabilirim. Yaptığım hareketlerin onları ne kadar üzdüğünü veya mutlu ettiğini, bununla ilgili duygularını anlamak için yüz ifadelerine dikkat edebilirim (K4).

Hayatta ne istediğimi bilen biri olarak daha rahat adım atmamı sağlar bazı durumlar. Beni daha mutlu daha aktif bir insan yapar (K14).

Psikolojik danışman adaylarının becerinin kullanma niteliğine ilişkin görüşleri; daha doğru olarak, daha rahat olarak, daha dikkatli olarak, duygusal açıdan kontrollü olarak ve soğukkanlı olarak şeklinde sınıflandırılmıştır. Bu konuda katılımcıların görüşlerine örnek olabilecek alıntılar aşağıda yer almaktadır.

Eğer küçük bir grubun içinde çok rahat yapabildiysem toplum içinde de çok rahat uygularım (K12).

Günlük hayattaki sorumluluklarımı yerine getirirken artık daha dikkatli davranacăğm (K9).

Insanlara davranırken atılgan olmanın daha avantajlı ve iyi olduğunu fark ettim. Bu yüzden çok sinirli anlarda bile saldırgan tutumlardan geri kalabilirim (K4).

Psikolojik danışman adaylarının becerinin katkısına ilişkin görüşleri; mutlu olma, özgüvenli olma, güvenilir olma, rahat olma, özerk olma, hoşgörülü olma, girişimci olma ve aktif olma şeklinde sınıflandırılmıştır. $\mathrm{Bu}$ konuda katılımcıların görüşlerine örnek olabilecek alıntılar aşağıda yer almaktadir.

Daha mutlu olmamı sağlar en başında. Insanın kendini bilmesi bana göre insana mutluluk sağllyor. Kendinin farkında olmak hataları düzeltebilmek doğruları devam ettirebilmek demektir. Bu oturumdaki becerilerin daha dikkatli olmamı sağlayacağını düşünüyorum, kendimi 
düzeltebilmek anlamında kendi doğrumu bulmak konusunda (K5).

Artık yabancılarla konuşurken daha özgüvenli konuşabiliyorum (K8).

Bir yerde sunum yapacă̆ım zaman artık daha rahat olup sesimi titretmeden anlatabilirim (K4).
Kararlarımı bundan sonra ben almayı düşünüyorum. Bu becerileri kendi başıma karar verirken kullanacă̆ım (K12).

Psikolojik danışman adaylarının oturumlarda yaşadıkları zorluklara ilişkin görüşleri Tablo 5'te sunulmuştur.

Tablo 4. Psikolojik Danışman Adaylarının Oturumlarda Yaşadıkları Zorluklara İlişkin Görüşleri

\begin{tabular}{lc}
\hline & $\mathbf{f}$ \\
Rol oynama & 5 \\
Form doldurma & 3 \\
Beden dilini kullanma & 2 \\
Karş1lıklı konuşma yapma & 1 \\
Göz teması kurma & 1 \\
Hazırlıksız konuşma yapma & 1 \\
Oturma düzeninden rahatsız olma & 1 \\
Topluluk önünde konuşma & 1 \\
Toplam & 1 \\
\end{tabular}

Psikolojik danışman adaylarının oturumlarda yaşadıkları zorluklara ilişkin görüşleri; rol oynama, form doldurma, karşılıklı konuşma yapma, göz teması kurma, beden dilini kullanma, hazırlıksız konuşma yapma, oturma düzeninden rahatsız olma ve topluluk önünde konuşma şeklinde sınıflandırılmıştır. $\mathrm{Bu}$ konuda katılımcılar görüşlerini aşağıdaki gibi dile getirmişlerdir.

Bence oturumda yapilabilecekler yapıldi. Rol oynamak benim için zordu. Açıkçası pek de istemedim. Ilave olarak yapulacak uygulamalar oturumda kazanacaklarımı törpüleyebilir. Kişisel olarak daha da geri durmayı düşünebilirdim. Samimi ve yararlıydı (K2).
En zorlayıcı olan insanlarla karşı karşıya konuşabilmek, göz teması yapabilmekti (K1).

En zorlayıcı şeyler konuşmadan bir şeyler anlattı̆̆ımı bölümlerdi (K5).

En zorlandığım şey ekrandaki resimleri yorumlayıp arkadaşlara anlatmak (K6).

Psikolojik danışman adaylarının sosyal beceri eğitim programı ve sürecine ilişkin görüşleri Tablo 6'da sunulmuştur.

Tablo 5. Psikolojik Danışman Adaylarının Sosyal Beceri Eğitim Programı ve Sürece İlişkin Görüşleri

\begin{tabular}{|c|c|}
\hline \multirow{2}{*}{\multicolumn{2}{|c|}{$\begin{array}{l}\text { Yeterli Görme } \\
\text { Uygun etkinlik }\end{array}$}} \\
\hline & \\
\hline Amaca uygun olma & 14 \\
\hline Gerçek yaşamdan olma & 5 \\
\hline Yararle oturumlar & 14 \\
\hline Topluluk önünde konuşma & 4 \\
\hline Empati & 4 \\
\hline Hepsi & 4 \\
\hline Duygular ve beden dili & 2 \\
\hline Sürec & 12 \\
\hline Güzel & 3 \\
\hline Yararlı & 3 \\
\hline Eğlenceli & 2 \\
\hline Eğitici & 2 \\
\hline Samimi & 1 \\
\hline Kendini tanımaya yardımcı & 1 \\
\hline Uygun teknikler & 8 \\
\hline Rol oynama & 7 \\
\hline Beyin firtınası & 1 \\
\hline Toplam & 55 \\
\hline Yetersiz Görme & \\
\hline Etkinlik sayısı & 6 \\
\hline Yararsiz oturumlar & 5 \\
\hline Empati & 2 \\
\hline Sorumluluk & 1 \\
\hline İletişim başlatma ve sürdürme & 1 \\
\hline Karar verme & 1 \\
\hline Oturum süresi & 5 \\
\hline Ödev saylsı & 3 \\
\hline Oturum saylst & 1 \\
\hline Toplam & 20 \\
\hline Genel toplam & 73 \\
\hline
\end{tabular}


Sosyal beceri eğitim programı ve süreç teması "yeterli görme" ve "yetersiz görme" olmak üzere iki alt temadan oluşmaktadır. Psikolojik danışman adaylarının sosyal beceri eğitim programı ve sürece ilişkin değerlendirmeleri analiz edildiğinde programı ve süreci yeterli görüldüğü ortaya çıkmıştır. Yeterli görenlerin etkinliklerin amaca uygunluğuna ve gerçek yaşamdan olmasına dikkat çektikleri görülmektedir. Topluluk önünde konuşma, empati, duygular ve beden dili oturumları bazı katılımcılar tarafindan yararlı oturumlar olarak ifade edilirken, bazı katılımcılar ise oturumların hepsinin yararlı olduğunu ifade etmişlerdir. Katılımcıların sürece ilişkin görüşleri; güzel, yararlı, eğlenceli, eğitici, samimi ve kendini tanımaya yardımcı şeklinde genellikle olumlu nitelendirmelerden oluşmaktadır. Bazı katılımcılar rol oynama ve beyin firtınası tekniklerini uygun teknikler olarak değerlendirmişlerdir. Bu konuda katılımcıların görüşlerine örnek olabilecek alıntılar aşağıda yer almaktadır.

$\mathrm{Bu}$ beceriyi geliştirmenin en iyi yolu insanların önüne çıkıp bir șeyler anlatmayla olurdu. Onu da zaten hocamız yaptı daha farklı bir şey olamazdı herhalde (K14). için (K6).

Duygular ve beden dili en yararlı oturumdu benim

Süreci genel olarak değerlendirmek için kafamda canlandırdiğım görüntülerin çoğunda kendimi gülerken görüyorum. Herkesin de bildiği gibi bu iyi bir şey. Süreç genel olarak güzeldi...(K3).
...Eğlenceli ve yararlıydl. Evet yararlıydı çünkü her oturumun sonunda başka bir farkındalıkla oradan ayrllyyorduk (K3).

Bence bu konuda en iyi uygulama rol yapmayd zaten bunu da hocamız yaptırdı (K12).

Psikolojk danışman adaylarının sosyal beceri eğitim programı ve sürece ilişkin değerlendirmeleri analiz edildiğinde aşağıdaki alıntılarda görüleceği gibi yetersiz olarak ifade edilen hususlar; etkinlik sayısı, ödev sayısı, oturum süresi, oturum sayısı ve yararsız oturumlar şeklinde sınıflandırılmıştır. Empati, sorumluluk, iletişimi başlatma ve sürdürme ve karar verme oturumları bazı katılımcılar tarafından yararsız oturum olarak değerlendirilmiştir.

\section{Etkinlik ve süre azdı (K6).}

Sorumluluk alma idi. Çünkü bana göre sorumluluk alma güzel bir şey değil ama bunu olumlu gerçekleştirmek ise harika denilebilir (K1).

Oturumların daha uzun olmasi gerektiğini düşünüyorum. Programda eksiklik yoktu. Sadece dişarıda sosyal beceriyi geliştirecek etkinlikler olmall diye düşünüyorum (K10).

Psikolojik danışman adaylarının oturumlarda ele alınan becerileri geliştirmeleri için oturumlarda nelerin yapılabileceğine ilişkin önerileri Tablo 7' de sunulmuştur.

Tablo 6. Psikolojik Danışman Adaylarının Oturumlarda Ele Alınan Becerileri Geliştirmeleri İçin Oturumlarda Nelerin Yapılabileceğine İlişkin Önerileri

\section{Öneri}

Başka etkinlikler olmalı

Beden dili ile ilgili başka etkinlik

Tek senaryo ile oynanmalı

Duygu değişimi ile ilgili etkinlik olmalı

Form doldurma olmamal1

Günlük hayatla ilgili başka etkinlik

İş birliği çalışması olmalı

Eğlenceli oyunlar olmalı

Etkinlik saylsi arttırılmalı

Oturum süresi arttırllmalı

Ödev daha çok verilmeli

Oturum sayisı arttırllmalı

Konu saylsi azalttlmalı

Toplam

Fikir yok

Toplam

Genel toplam

Psikolojik danışman adayları oturumlarda ele alınan beceriyi geliştirmeleri için oturumların içeriğine ve sürecine ilişkin önerilerde bulunmuşlardır. $\mathrm{Bu}$ öneriler; başka etkinlikler olmalı, etkinlik sayısı arttırılmalı, oturum süresi arttırılmalı, ödev daha çok verilmeli, oturum sayısı arttırılmalı ve konu sayısı azaltılmalı şeklinde sınıflandırılmıştır. Dört katılımcı fikir beyan etmemiştir. Bu konuda katılımcıların görüşlerine örnek olabilecek alıntılar aşağıda yer almaktadır. $\mathbf{f}$ 8 1 1 1 önce doldururken çok zorlandırdım. Ama bu sefer çok rahat bir şekilde doldurdum. Buna ben de şaşırdım. Bence form

doldurma şeklinde yapmaktan çok o sorulart siz bize sözel olarak sorsaydınız. Biz bir anda doğaçlama cevap verseydik bence daha doğru net cevaplara ulaşırdık. Yani bize süre verdiğiniz zaman biz oraya düşünüp istediğimiz cevaplarl yazlyoruz. Daha hazırlıksı yakalansaydık sorulara, bir anda aslına en gerçekçi cevabı sizlere verirdik bence. Yine de güzeldi (K3). 
Eksiklik bence etkinliklerin az olmasindaydl. Etkinliklerin fazla olmasını öneririm (K1)

\section{Sonuç ve Öneriler}

$\mathrm{Bu}$ çalışmada sosyal beceri eğitimi yoluyla psikolojik danışman adaylarının sosyal beceri ve psikolojik iyi olma düzeyleri arttırılarak, mesleki yaşamlarında etkili birer psikolojik danışman olmalarına katkı sağlanabileceği düşüncesiyle hareket edilmiştir. Programın faydalı olup olmadığı ve ileride geliştirilecek programlara fikir vermesi açısından katılımcıların görüşlerine başvurulmuştur.

Genel bir değerlendirme yapıldığında psikolojik danışman adaylarının çoğunun oturumların amaçları doğrultusunda kazanımlar elde ettikleri, oturumlarda kendilerinde var olan özelliklerini fark ettikleri, kendilerini geliştirme ihtiyacı hissettikleri, süreçte hoş zaman geçirdikleri, oturumları eğitici ve yararlı buldukları, elde ettikleri becerileri nerede ve nasıl kullanacakları, becerinin kendilerine katkısı konusunda fikir sahibi oldukları görülmüştür. Eğitim sonunda ilişkiyi başlatma ve sürdürebilme becerileri, grupla bir işi yürütme becerileri, duygulara yönelik beceriler, saldırgan davranışlarla başa çıkabilme becerileri, plan yapabilme ve problem çözme becerilerinde gelişmeler sağladıklarını belirtmişlerdir. Oturumların, kendilerinin mutlu olma, özgüvenli olma, güvenilir olma, rahat olma, özerk olma, hoşgörülü olma, girişimci olma ve aktif olma yönlerine katkı sağladığını, kendilerini tanıdıklarını, özelliklerinin farkında olduklarını, kendilerini geliştirme ihtiyacı hissettiklerini, sorumluluk bilincinde olduklarını, sosyal ilişkilerini güçlendirme konusunda adım attıklarını ifade etmişlerdir. Tüm bu bulgulardan hareketle yapılan bu eğitimin etkili psikolojik danışmanlık için psikolojik danışman adaylarına olumlu katkı sağladığı ve yararlı olduğu söylenebilir.

Etkili psikolojik danışma yardımı sunmanın en önemli koşullarından biri psikolojik yardımı veren kişinin etkili bir psikolojik danışman olmasıdır (Hackney\&Cormier, 2005). $\mathrm{Bu}$ da psikolojik danışman adaylarının alacakları eğitim, sahip olacakları bilgi, beceri ve geçirdikleri deneyimler ile mümkün görünmektedir. $\mathrm{Bu}$ çalışma ile psikolojik danışman adaylarının ileride etkili bir psikolojik danışman olmaları için gereken özelliklerden biri olan güçlü sosyal ilişkiler kurma ve psikolojik iyi olma konusunda gelişme sağlandığı ve aynı zamanda bu çalışmanın psikolojik danışman adaylarına deneyim imkânı sağladığı düşünülmektedir. Sonuçların böyle çıkmasında şüphesiz sosyal beceri eğitiminin içeriğinin, oturum sürecinin doğru işlenişinin, oturum sürecinde grup liderinin aldığı süpervizyönün, grup liderinin katılımcılara karşı tutumunun payı olduğu kadar, katılımcıların da ön görüşmeden son oturuma kadar eğitime düzenli katılımlarının, istekli olmalarının, kendileri için bir şey yapma gayreti içerisinde olmalarının payının büyük olduğu düşünülmektedir.

Alan yazın incelendiğinde psikolojik danışman adaylarına yönelik eğitimlerin faydalı olduğu, adaylara katkı sağladığı ve adayların kendilerini geliştirmeleri için uygulamalı eğitimlerin yapılması yönünde görüş vardır. Atıcı, Sanberk ve Ortakale (2011) psikolojik danışma sürecinin büyük ölçüde "psikolojik danışmanın kişiliğinden ve terapötik
Aslında daha farklı neler yaplabilirdi bilmiyorum ama iyi oldu. Aslında kendimi pek tanımadığımı anladım (K11)

ilişkiden etkilendiğini, danışmanlık veya psikoterapi eğitiminde danışmanın eğitim sürecindeki kişisel deneyimlerinin mesleki yeterlilik üzerinde rol oynadığını" ifade etmişlerdir. PDR lisans eğitimine devam eden 3. sınıf öğrencileri ile yaptıkları araştırmada "grup rehberliği etkinliklerine katılan öğrencilerin bu etkinlikleri yürütürken kullanılan eylem ve becerileri fark etme, önemini anlama, becerileri kullanma konusunda güven ve gelişim gösterdikleri” sonucuna varmışlardır. Ayrıca "duygu ve düşüncelerini fark etme ve ifade etme, bazı düşünce ve davranışlarını değiştirme, insanları tanıma ve anlama, iletişim becerilerini geliştirme" gibi konularda ilerleme gösterdikleri bulunmuştur.Öner Altıok (2013) profesyonel sosyalizasyon teorisine temellendirilen psiko-eğitim programının öğrencilerin sosyal beceri düzeylerine etkisini incelediği araştırmasında öğrencilerin programa yönelik geribildirimlerini almıştır. Öğrenciler, grup çalışmaları sonunda "kendini önemseme, güvende hissetme, motivasyon ve olumlu düşüncede artış, dinleme, empati ve kendini ifade etme becerilerinde artış, olayları irdeleme, atılgan olma ve ders dışı bir etkinlikte bulunmaktan ve grupla çalışmaktan memnun olma gibi olumlu değişimler yaşadıklarını" ifade etmişlerdir. Yaka (2013), mikro beceri eğitimi programının psikolojik danışman adaylarının psikolojik danışma becerilerine etkisini incelediği araştırmasında beceri eğitimi yönteminin dikkati verme, soru sorma, asgari düzeyde teşvik etme, içerik yansıtma, duygu yansıtma becerilerini öğretmede oldukça etkili ve istikrarlı olduğunu bulmuştur.Meydan (2015), psikolojik danışman adaylarının psikolojik danışma becerilerinin köşe taşı olarak nitelendirilen içerik yansıtma ve duygu yansıtma becerilerinin yeterlik düzeylerini belirlemeye yönelik yaptığı çalışmasında sonucu orta düzeyde bulmuş ve duygu yansıtma becerisinin psikolojik danışman adaylarına daha etkili bir biçimde nasıl kazandırılabileceğine ilişkin bazı çalışmaların yapılması ve ilgili derslerin yeniden yapılandırılmasının da yararlı olabileceğini ifade etmiştir.Ayrıca uygulama yapma, model sunmave geribildirim alma psikolojik danışma becerilerinin öğretiminde etkili yöntemler olarak ifade edilmektedir (Hill\&Lent, 2006;Kasdorf\&Gustafson, 1978).

Diğer taraftan psikolojik danışman adaylarının bazıları aldıkları bu eğitimde etkinlik ve ödev sayılarını, oturum süresini yetersiz görmüşlerdir. Başka etkinlikler de olmasını, etkinlik sayısının, oturum süresinin ve ödev sayısının arttırılmasını ifade etmişlerdir. Psikolojik danışman adaylarının ifade ettikleri bu noktalar bu tür programların hazırlanmasında ve uygulanmasında dikkate alınması gereken noktalar olarak karşımıza çıkmaktadır. $\mathrm{Bu}$ tür programların daha verimli olması yönünde program hazırlayıcılara ve uygulayıcılara fikir vermektedir.

Sonuç olarak bu araştırma psikolojik danışman adaylarının yetiştirilmesi sürecinde sadece alınan teorik derslerin yeterli olmadığı, uygulamalı eğitimlerin psikolojik danışma becerilerine katkı sağladığ 1 fikrini destekler niteliktedir. Bu ve buna benzer programların geliştirilerek psikolojik danışman yetiştirme sürecinde adaylara uygulanmasının etkili psikolojik danışmanlık hizmetleri için gerekli olduğu 
düşünülmektedir. Ayrıca program geliștiriciler için bu araştırma bulgularında ortaya çıkan etkinlik sayısı, süre, ödev sayısı gibi faktörlere dikkat edilmesi programın ve eğitimin etkililiği için önemli görülmektedir.

\section{Kaynakça}

Akkoyun, F. (2001). Transaksiyonel analiz. İstanbul. Nobel Yayın Dağıtım.

Akkök, F. (1996). Ilköğretimde sosyal becerilerin geliştirilmesi, ögretmen el kitabl. İstanbul: MEB Yayınevi.

Atıcı, M. (2006). İlköğretim öğrencilerinin davranış problemleriyle baş etme konusunda öğretmen-psikolojik danışman işbirliğine ilişkin görüşlerin karşılaştırılması. Türk Psikolojik Danışma ve Rehberlik Dergisi, 3(25), 55-68.

Atıcı, M., Sanberk, İ. \&Ortakale, M. Y. (2011). Mesleki ve kişisel gelişim açısından pdr üçüncü sınıf öğrencilerinin grup rehberliği etkinliklerine ilişkin görüşlerinin incelenmesi. Çukurova Üniversitesi Sosyal Bilimler Enstitüsü Dergisi, 20(3), 459-474.

Corey, G. (1996). Theoryandpractice of counselingandpsychotherapy. California: Brooks/ Cole Publishing Company.

Dikmeer, İ.D. (1997). Sosyal beceri eğitiminin sosyal içe dönük ergenlerin içe dönüklük düzeylerine etkisi. Yayınlanmamış yüksek lisans tezi, Ankara Üniversitesi, Ankara.

Dow, G. T. \&Mayer, R. E. (2004). Teachingstudentstosolveinsightproblems: Evidencefor domain specificity in creativitytraining. CreativityResearchJournals, 16 (14), 389-402.

George, D.\&Mallery, P. (2012). SPSS Statistics 21: Step by Step. Boston: Allynand Bacon.

Hackney, H. \&Cormier, S. (2005). Theprofessionalcounselor: A processguidetohelping. Boston: Pearson.

Hill, C. E. \&Lent, R. W. (2006). A narrativeand metaanalyticreview of helpingskillstraining: Time torevive a dormantarea of inquiry. Psychotherapy: Theory, Research.

Kasdorf, J. \&Gustafson, K. (1978). Researchrelatedtomicrotraining. İçinde A. E. Ivey ve J. Authier (Ed.), Microcounseling: Innovations in interviewing, psychotherapyandpsychoeducation (s. 323-376) Springfield, IL: Charles C. Thomas.

Kepçeoğlu, M. (2000). Psikolojik danışma ve rehberlik. İstanbul: Alkım Yayınları.

Keyes, C. L. M.,Shmotkin, D. \&Ryff, C. D. (2002). Optimizing well-being: Theempiricalencounter of twotraditions. Journal of PersonalityandSocialPsychology, 82(6), 1007-1023.
Korkut-Owen, F.,Tuzgöl Dost, M., Bugay, A. \&Owen, D.W. (2014). Psikolojik danışman eğitiminde mesleğe ilişkin kişisel eğilimler. Ege Eğitim Dergisi, 15(1), 300317.

Markert, L. F. \&Monke, R. H. (1990). Changes in counseloreducationadmissionscriteria. CounselorEducationandSupervision, 30, 48-57.

Meydan, B. (2015). Psikolojik danışman adaylarının içerik yansıtma ve duygu yansıtma becerilerine ilişkin yeterlik düzeylerinin incelenmesi. Hacettepe Üniversitesi Ĕ̈itim Fakültesi Dergisi (H. U. Journal of Education) 30(4), 115

Miles, M.B. \&Huberman, A.M. (1994). Qualitativedataanalysis. Newbury Park, CA: Sage.

Muslu Köseoğlu, S. (1994). Psikolojik danışmanların empatik becerilerinin ve kişilik özelliklerinin incelenmesi. Yayınlanmamış yüksek lisans tezi, Marmara Üniversitesi, İstanbul.

Myrick, R. D

Developmentalguidanceandcoungseling:

practicaapproach. Minneapolis: Educational Media Corporation.

Öner Altıok, H. (2013). Profesyonel sosyalizasyon teorisine temellendirilen psikoeğitim programının hemşirelik öğrencilerinin sosyal beceri düzeylerine etkisi. Yayınlanmış doktora tezi, Dokuz Eylül Üniversitesi, İzmir.

Özgüven, İ.E. (1999). Çăğdaş eğitimde psikolojik danışmanlık ve rehberlik. Ankara: Pdrem Yayınları.

Paisley, P. O. \& Hayes, R. L. (2003). School counseling in theacademic domain: Transformation in preparationanadpractice. Professional School Counseling, 6, 198-204.

Rutherford, R.B.,Mathur, S.R., \&Quinn, M.M. (1998). Promotingsocialcommunicationskillsthroughcooperative learninganddirectinstruction. EducationandTreatment of Children, 21 (3), 354-369.

Tan, H. (1992). Psikolojik danışma ve rehberlik. İstanbul: Alkım Yayınevi.

Turner, R. C. \&Carslon, L. (2003). Indexes of itemobjectivecongruenceformultidimensionalitems. International Journal of Testing, 3(2), 163-171.

Ülkü, S. (1977). Rehberlikte grup yaklaşımı. Ankara Üniversitesi Eğitim Fakültesi Dergisi, 9(1-4), 263-299.

Voltan Acar, N. (2001). Grupla psikolojik danışma ilke ve teknikleri. Ankara: Nobel Yayın Dağıtım.

Yaka, B. (2013). Mikro Beceri Eğitimi Programı'nın psikolojik danışman adaylarının psikolojik danışma becerilerine etkisi. Ege Eğitim Dergisi, 14(2), 1-24.

Yıldırım, A. \& Şimşek, H. (1999). Sosyal bilimlerde nitel araştırma yöntemleri. Ankara: Seçkin Yayınevi.

Yüksel, G. (1997). Sosyal beceri eğitiminin üniversite öğrencilerinin sosyal beceri düzeyine etkisi. Yayınlanmamış doktora tezi, Gazi Üniversitesi, Ankara. 
Canpolat, M. \& Atıcı, M. / Anemon Muş Alparslan Üniversitesi Sosyal Bilimler Dergisi, 20197 [Eğitim\&Psikoloji] xx-xx148 